\title{
MENINGKATKAN KEMAMPUAN KONEKSI MATEMATIK SISWA SMP DENGAN MENGGUNAKAN PENDEKATAN REALISTIC MATHEMATIS EDUCATION
}

\author{
Neneng Yulia Wulandari \\ Pascasarjana IKIP Siliwangi Bandung \\ Wulandariyulia32@gmail.com
}

Penerimaan : 7 Agustus 2018

Diterima: 10 Juni 2019

\begin{abstract}
ABSTRAK
Penelitian ini dilatarbelakangi oleh rendahnya kemampuan koneksi matematik siswa SMP. Penelitian ini bertujuan untuk menelaah pencapaian dan peningkatan kemampuan koneksi matematik siswa SMP yang pembelajarannya menggunakan pendekatan Realistic Mathematis Education dibandingkan dengan yang menggunakan pembelajaran biasa. Metode pada penelitian ini adalah metode eksperimen dengan desain penelitian pretes-postes. Populasi dalam penelitian ini adalah siswa SMP AL-Madina Cianjur, sedangkan sampel penelitiannya yaitu kelas VII yang dipilih secara acak dari salah satu SMP di Cianjur dan terpilih kelas VII A sebagai kelas eksperimen dan kelas VII C sebagai kelas kontrol. Kelas eksperimen menggunakan pembelajaran dengan pendekatan Realistic Mathematis Education sedangkan kelas kontrol menggunakan pembelajaran biasa. Instrumen dalam penelitian ini adalah seperangkat soal tes kemampuan koneksi matematik yang terdiri dari lima soal tes uraian, data yang akan diolah dalam penelitian ini adalah skor pretes, postes, dan N-gain yang diolah menggunakan bantuan sofware SPSS 16 dan Minitab 16. Hasil penelitian yang diperoleh yaitu pencapaian kemampuan koneksi matematik siswa SMP yang pembelajarannya menggunakan pendekatan Realistic Mathematis Education lebih baik daripada yang menggunakan pembelajaran biasa, peningkatan kemampuan koneksi matematik siswa SMP yang pembelajarannya menggunakan pendekatan Realistic Mathematis Education lebih baik daripada yang menggunakan pembelajaran biasa, serta implementasi langkah-langkah pembelajaran dengan menggunakan pendekatan Realistic Mathematis Education di lapangan sudah terlaksana.
\end{abstract}

Kata Kunci: Koneksi Matematik, Pendekatan Realistic Mathematis Education

\section{PENDAHULUAN}

Tujuan pendidikan matematika menurut Depdiknas No. 22 tahun 2006 menyatakan bahwa mata pelajaran matematika bertujuan agar peserta didik memiliki kemampuan sebagai berikut; 1) Memahami konsep matematika, menjelaskan keterkaitan antar konsep dan mengaplikasikan konsep atau alogaritma secara luwes, akurat, efisien, dan tepat dalam pemecahan masalah; 2) Menggunakan penalaran pada pola dan sifat, melakukan manipulasi matematika dalam membuat generalisasi, menyusun bukti atau menjelaskan gagasan matematika dan pernyataan matematika; 3) Memecahkan masalah yang meliputi kemampuan memahami masalah, merancang model matematika, menyelesaikan model matematika dan menafsirkan solusi yang di peroleh; 4) Mengkomunikasikan gagasan 
dengan symbol, tabel, diagram atau media lain untuk memperjelas keadaan atau masalah; 5) Memiliki sikap menghargai kegunaan matematika dalam kehidupan, yaitu memiliki rasa ingin tahu, perhatian, dan minat dalam pemecahan masalah.

Berdasarkan tujuan pembelajaran matematika di atas, kemampuan koneksi matematik merupakan salah satu kemampuan yang penting dimiliki oleh siswa, hal itu sesuai dengan pendapat Hermawan (2007) yang menyatakan bahwa fungsi dari pembelajaran matematika yaitu untuk mengembangkan kemampuan koneksi matematik karena siswa diharapkan dapat mengkaitkan matematika dengan disiplin ilmu lain maupun dalam kehidupan sehari-hari. Kemampuan koneksi matematik menjadi sangat penting karena akan membantu siswa dalam penguasaan pemahaman konsep yang bermakna dan membantu menyelesaikan masalah melalui keterkaitan antara konsep matematika dengan konsep dalam disiplin ilmu lain ataupun dalam kehidupan sehari-hari. Dengan demikian kemampuan koneksi matematik ini akan membantu siswa dalam menyusun model matematika yang juga menggambarkan keterkaitan antar konsep suatu masalah dengan situasi yang diberikan. Berdasarkan hal tersebut tanpak bahwa kemampuan koneksi matematik itu sangat penting dimiliki oleh siswa.

Kenyataan di lapangan, rendahnya kualitas kemampuan matematik siswa Indonesia tercermin dari hasil survei internasional Programme for International Student Assesment (PISA). Pada hasil PISA (2012), Indonesia hanya menduduki peringkat 64 dari 65 negara peserta dengan skor rata-rata 375, padahal rata-rata skor internasional adalah 494. Ratarata skor 375 menunjukkan bahwa kemampuan matematik siswa Indonesia terletak pada level terbawah. Kemampuan koneksi matematik adalah salah satu aspek yang dilihat pada soal PISA, sehingga dapat disimpulkan bahwa kemampuan koneksi matematik siswa Indonesia tergolong rendah.

Berdasarkan pemaparan di atas, dapat kita simpulkan bahwa siswa tidak mampu menghubungkan antar konsep yang satu dengan konsep yang lain. Permasalahan tersebut harus segera ditangani, salah satunya dengan menggunakan pendekatan pembelajaran yaitu pendekatan Realistic Mathematis Education. Seperti yang diungkapkan Sabandar (Riajanto, 2010) bahwa pendekatan Realistic Mathematis Education adalah salah satu alternatif pendekatan pembelajaran, dalam pendekatan Realistic Mathematis Education, dunia nyata digunakan sebagai titik awal untuk mengembangkan ide dan konsep matematika sehingga siswa diarahkan dan diberi kesempatan untuk menemukan konsep 
dan ide sendiri. Salah satu karakteristik dari pendektan Realistic Mathematis Education adalah mengangkat permasalahan dalam dunia nyata, sehingga siswa didorong untuk dapat mengkoneksikan pemahamannya dengan dunia nyata, kemudian terdapat pula karakteristik Intertwining, yang mana karakteristik tersebut mendorong siswa mengkoneksikan konsep yang satu dengan konsep yang lainnya, dengan demikian pembelajaran dengan pendekatan Realistic Mathematis Education ini diduga dapat meningkatkan kemampuan koneksi matematik. Dalam pembelajaran dengan menggunakan pendekatan Realistic Mathematis Education, siswa diberi kesempatan untuk menyelidiki, mengemukakan dan memahami konsep matematika melalui suatu masalah dalam situasi yang nyata dalam kehidupan sehari-hari yang bersifat nyata sehingga siswa mempunyai peengertian yang kuat tentang konsep-konsep matematika.

Berdasarkan latar belakang masalah yang telah dikemukakan di atas, maka peneliti tertarik untuk melakukan penelitian pembelajaran dengan judul "Meningkatkan Kemampuan Koneksi Matematik Siswa SMP dengan Menggunakan Pendekatan Realistic Mathematis Education.

\section{Kemampuan Koneksi Matematis}

Ramdani (2012) koneksi matematis merupakan pembelajaran harus lebih ditekankan pada: (1) pengertian kelas sebagai komunitas matematika daripada hanya sebagai sekumpulan individu; (2) pengertian logika dan kejadian matematika sebagai verifikasi daripada guru sebagai penguasa tunggal dalam memperoleh jawaban benar; (3) pandangan terhadap penalaran matematika daripada sekadar mengingat prosedur atau algoritma; (4) penyusunan konjektur, penemuan dan pemecahan masalah daripada penemuan jawaban secara mekanik; dan (5) mencari hubungan antara ide-ide matematika dan penerapannya daripada matematika sebagai sekumpulan konsep yang saling terpisah.

NCTM (Ruspiani, 2000), kemampuan koneksi matematis adalah kemampuan siswa dalam mengaitkan konsep-konsep mamtematika baik antar konsep matematika itu sendiri (dalam matematika) maupun mengaitkan konsep matematika dengan bidang lainnya (luar matematika). Sumarmo (2012) memaparkan beberapa indikator kemampuan koneksi matematis diantaranya: (1) memahami hubungan berbagai representasi konsep dan prosedur matematika; (2) mencari hubungan berbagai representasi konsep, proses, atau prosedur matematika; (3) Memahami antar topik matematika; (4) menerapkan matematika dalam bidang lain atau dalam kehidupan sehari-hari; (5) mencari hubungan satu prosedur 
lain dalam representasi yang ekuivalen; (6) menerapkan hubungan antar topik matematika dan antara topik matematika dengan topik di luar matematika.

Dari pernyataan di atas dapat disimpulkan, terdapat tiga tujuan pembelajaran matematika yang menekankan pada koneksi matematis siswa, yaitu: memperdalam pemahaman siswa, melihat hubungan matematika pada interaksi yang kaya dan dapat menghubungkan antar topik pelajaran lain dan kehidupan sehari-hari. Melalui instruksi yang menekankan keterkaitan ide-ide matematika, siswa tidak hanya belajar matematika, mereka juga belajar tentang kegunaan matematika. Sehingga dalam penelitian ini indikator kemampuan koneksi yang dipakai adalah; 1) kemampuan koneksi antar topik matematika; 2) kemampuan koneksi antar topik matematika dengan bidang studi ilmu lain; 3) kemampuan koneksi dalam kehidupan sehari-hari.

\section{a. Pendekatan Realistic Mathematic Education}

Pendekatan Realistik Realistic Mathematis Education adalah suatu teori pembelajaran yang telah dikembangkan khusus untuk matematika. Menurut Freudenthal (Wijaya, 2012) bahwa "matematika merupakan suatu bentuk aktivitas manusia". Pendidikan Matematika Realistic Mathematis Education merupakan suatu pendekatan dalam pembelajaran matematika di Belanda. Penggunaan kata "realistic" tersebut tidak sekedar menunjukan adanya suatu koneksi dengan dunia nyata (real-world) tetapi lebih mengacu pada focus Pendidikan. Realistic Mathematis Education dalam menempatkan penekanan penggunaan suatu situasi yang bisa dibayangkan (imagineable) oleh siswa."

Usdiyana. (Ruseffendi, 2001) Karakteristik Pendekatan Matematika Realistik (PMR) adalah sebagai berikut: menggunakan masalah kontekstual, menggunakan model, menggunakan kontribusi siswa, adanya interaksi dalam proses pembelajaran, dan menggunakan berbagai teori belajar yang relevan, saling terkait, dan terintegrasi dengan topik pembelajaran lainnya.

Treffers (Wijaya, 2012) merumuskan lima karakteristik Pendidikan Matematika Realistic Mathematis Education yaitu:

1. Penggunaan konteks

konteks atau permasalahan realistik yang digunakan sebagai titik awal pembelajaran matematika.

2. Penggunaan model untuk matematisasi progresif 
Dalam pendekatan realistik, model digunakan dalam melakukan matematisasi secara progresif.

3. Pemanfaatan hasil kontribusi siswa

Matematika tidak diberikan kepada siswa sebagai suatu produk yang siap dipakai tetapi sebagai suatu konsep yang dibangun oleh siswa maka dalam pendekatan Realistic Mathematis Education ditempatkan sebagai subjek belajar.

4. Interaktivitas

Proses belajar seseorang bukan hanya suatu proses individu melainkan melainkan secara bersamaan merupakan suatu proses sosial.

\section{Keterkaitan}

konsep-konsep dalam matematika tidak bersifat parsial, namun banyak konsep matematika yang memiliki keterkaitan. Oleh karena itu, konsep-konsep matematika tidak dikenalkan kepada siswa secara terpisah atau terisolasi satu sama lain.

Selanjutnya karakteristik PMR menurut Gravemeijer (Zaini, dkk. 2014), yaitu (1) Menggunakan konteks lingkungan keseharian sebagai sarana belajar matematika adalah untuk membuat hubungan antara pengetahuan yang dimiliki siswa dengan yang akan dipelajarinya. (2) Penggunaan model yang diarahkan pada model konkret meningkat ke abstrak memberikan kesempatan kepada siswa mengembangkan penalaran dan komunikasi matematik serta kreatifitas. (3) Penggunaan kontribusi siswa yang besar pada proses belajar mengajar diharapkan mendorong kreatifitas maupun penalaran dan kepribadian siswa untuk berani dan mau berbagi pemikiran maupun pendapat dalam menyelesaikan suatu masalah. (4) Interaktivitas yang diperhatikan dalam pembelajaran seperti interaksi, negosisasi secara eksplisit, intervensi, kooperasi dan evaluasi sesama siswa, siswa-guru. Proses belajar mengajar dalam PMR berlangsung secara interaktif, dan siswa menjadi fokus dari semua aktifitas di kelas. Kondisi ini mengubah otoritas guru yang semula sebagai satusatunya pusat dan sumber pengetahuan menjadi seorang pembimbing.

\section{METODE PENELITIAN}

Metode pada penelitian ini adalah metode eksperimen dengan desain penelitian pretes-postes. Populasi dalam penelitian ini adalah siswa SMP di Cianjur, sedangkan sampel penelitiannya yaitu kelas VII yang dipilih secara acak dari salah satu SMP di Cianjur dan terpilih kelas VII A sebagai kelas eksperimen dan kelas VII C sebagai kelas kontrol. Kelas eksperimen menggunakan pembelajaran dengan pendekatan Realistic Mathematis Education sedangkan kelas kontrol menggunakan pembelajaran biasa. 
Instrumen dalam penelitian ini adalah seperangkat soal tes kemampuan koneksi matematik yang terdiri dari lima soal tes uraian, data yang akan diolah dalam penelitian ini adalah skor pretes, postes, dan N-gain yang diolah menggunakan bantuan sofware SPSS 16 dan Minitab 16

\section{HASIL DAN PEMBAHASAN}

\section{Deskripsi Hasil Penelitian}

Berdasarkan pengolahan data pretes, postes dan $\mathrm{N}$-gain diperoleh rata-rata, persentase pencapaian kemampuan koneksi matematik dan simpangan baku dari kelas eksperimen dan kelas kontrol. Berikut tabel yang menyajikan nilai-nilai untuk masingmasing kelas.

Tabel 1. Deskripsi Data Kelas Eksperimen dan Kelas Kontrol

\begin{tabular}{ccccccc}
\hline \multirow{2}{*}{ Statistik } & \multicolumn{3}{c}{ Kelas Eksperimen } & \multicolumn{3}{c}{ Kelas Kontrol } \\
\cline { 2 - 7 } & Pretes & Postes & N-Gain & Pretes & Postes & N-Gain \\
\hline N & 30 & 30 & 30 & 30 & 30 & $\mathbf{3 0}$ \\
\hline- & 3,50 & 13,50 & 0,60 & 2,90 & 11,36 & $\mathbf{0 , 4 9}$ \\
$(\boldsymbol{\%})$ & 17,50 & 67,50 & & 14,50 & 56,83 & \\
\hline S & $\mathbf{1 , 2 5}$ & $\mathbf{3 , 4 0}$ & $\mathbf{0 , 2 1}$ & $\mathbf{1 , 2 1}$ & $\mathbf{3 , 2 8}$ & $\mathbf{0 , 1 9}$ \\
\hline
\end{tabular}

Skor Maksimal Ideal $=20$

Berdasarkan pada tabel 1 diperoleh rata-rata pretes untuk kelas eksperimen 3,50 dan kelas kontrol 2,90 terlihat bahwa tidak terdapat perbedaan yang signifikan pada ratarata untuk kemampuan awal kedua kelas sama. Pada kelas eksperimen rata-rata siswa memperoleh pretes kemampuan koneksi matematik sebanyak 17,50\% dan mengalami peningkatan pada postes sebesar 67,50\% dari rata-rata skor idealnya. Pada kelas kontrol rata-rata siswa memperoleh pretes kemampuan koneksi matematik sebanyak $14,50 \%$ dan mengalami peningkatan pada postes sebesar 56,83\% dari rata-rata skor idealnya. Dari data tersebut terlihat peningkatan pada kelas eksperimen sebesar 50,00\% dan kelas kontrol sebesar 42,33\% . Disimpulkan bahwa kelas eksperimen mengalami peningkatan yang lebih besar dibandingkan kelas kontrol yaitu sebesar 50,00\%.

Pada kelas eksperimen memiliki simpangan baku sebesar 3,40 sedangkan kelas kontrol simpangan bakunya 3,28 hal tersebut menunjukan bahwa kemampuan akhir pada kelas kontrol lebih menyebar daripada kelas eksperimen. 
Berdasarkan tabel yang sama, terlihat rata-rata N-gain kedua kelas yaitu 0,60 untuk kelas eksperimen dan 0,49 untuk kelas kontrol, sehingga dapat disimpulkan bahwa kelas eksperimen memiliki peningkatan kemampuan koneksi matematik yang lebih baik daripada kelas kontrol. Untuk menguji kebenarannya maka dilakukan perhitungan statistik secara inferensial untuk pretes, postes dan $\mathrm{N}$-gain yaitu dengan melakukan uji normalitas, uji homogenitas dan uji signifikansi perbedaan rata-rata.

Penelitian ini bertujuan untuk menelaah pencapaian kemampuan koneksi matematik siswa SMP yang pembelajaran dengan menggunakan pendekatan Realistic Mathematis Education dibandingkan dengan yang menggunakan pembelajaran biasa dan peningkatan kemampuan koneksi matematik siswa SMP pembelajaran menggunakakn pendekatan Realistic Mathematis Education dibandingkan dengan yang menggunakan pembelajaran biasa.

Sebelum dilakukan perlakuan yang berbeda pada kelas eksperimen dan kelas kontrol dalam penelitian ini, peneliti terlebih dahulu memberikan pretes pada kedua kelas tersebut berdasarkan analisis statistik deskriptif, terlihat bahwa nilai rata-rata pretes kedua kelas tidak terdapat perbedaan yang signifikan. Begitu juga dengan perhitungan statistik secara inferensial diperoleh kesimpulan bahwa tidak terdapat perbedaan kemampuan awal koneksi matematik siswa kelas eksperimen dan kelas kontrol.

Setelah dilakukan perlakuan yang berbeda kedua kelas diberikan postes untuk mengetahui perbedaan kemampuan koneksi matematik siswa dengan menggunakan pendekatan Realistic Mathematis Education. Pada analisis statistik desriptif, nilai rata-rata postes kelas eksperimen lebih besar daripada kelas kontrol. Begitu juga dengan perhitungan statistik secara inferensial diperoleh kesimpulan bahwa pencapaian kemampuan koneksi matematik siswa SMP yang pembelajarannya menggunakan pendekatan Realistic Mathematis Education lebih baik daripada siswa yang menggunakan pembelajaran biasa.

Pada analisis statistik desriptif, nilai rata-rata $\mathrm{N}$-gain kelas eksperimen lebih besar daripada kelas kontrol. Begitu juga dengan perhitungan statistik secara inferensial diperoleh kesimpulan bahwa peningkatan kemampuan koneksi matematik siswa SMP yang pembelajarannya menggunakan pendekatan Realistic Mathematis Education lebih baik daripada siswa yang menggunakan pembelajaran biasa. 
Pencapaian dan peningkatan kemampuan koneksi matematik siswa pada kelas eksperimen lebih baik daripada kelas kontrol. Hal tersebut dipengaruhi oleh kelancaran dalam pembelajaran serta antusias siswa selama pembelajaran, ini diduga pembelajaran yang menggunakan pendekatan Realistic Mathematis Education menuntut siswa untuk mengkoneksikan pemahamannya dengan dunia nyata dan mengkoneksikan konsep yang satu dengan konsep yang lainnya, sehingga pembelajaran yang terjadi lebih bermakna dan berjalan dengan lancar.

Berdasarkan hasil pembahasan di atas dapat diketahui bahwa kemampuan koneksi matematik siswa yang pembelajarannya menggunakan pendekatan Realistic Mathematis Education lebih baik daripada yang menggunakan pendekatan biasa, pendekatan Realistic Mathematis Education juga dapat meningkatkan kemampuan koneksi matematik siswa hal tersebut dikarenakan pendekatan Realistic Mathematis Education menuntut siswa untuk berperan aktif dalam mengkontruksikan dan mengkoneksikan pengetahuan mereka, selain dengan menerapkan pendekatan tersebut juga dengan adanya kelompok kecil dalam menggerjakan LKS yang diberikan, yang terdiri dari siswa pintar, sedang dan rendah dalam memahami suatu permasalahan dalam LKS yang diberikan, sedangkan peran seorang guru hanya menjadi fasilitator apabila ada kelompok yang kurang mengerti dalam permasalahan yang ada.

Berdasarkan pengamatan yang dilakukan peneliti, pada proses pembelajaran yang menggunakan pendekatan Realistic Mathematis Education terjadi proses interaksi yang dilakukan oleh siswa. hal tersebut terlihat pada gambar dibawah ini:

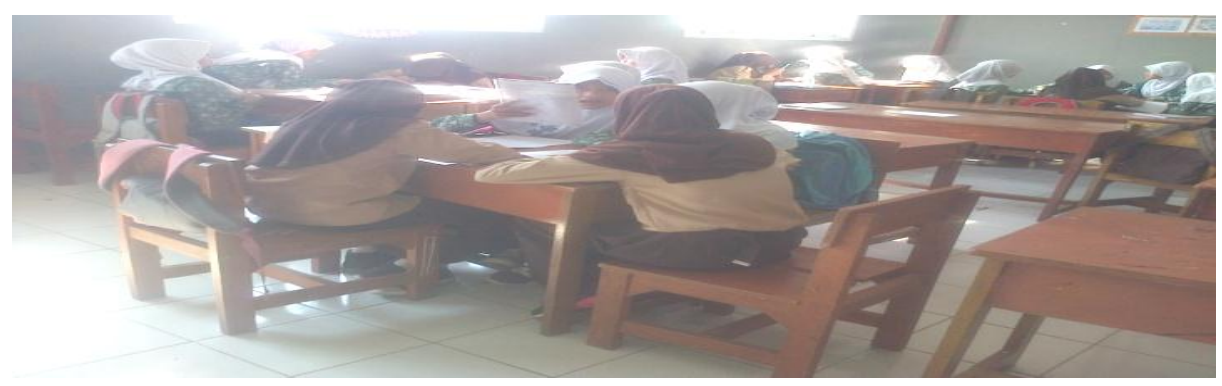

Gambar 1. Interaktivitas Siswa 
Pada proses interaksi tersebut terjadi diskusi antar siswa berupa penyampaian ideide dan gagasan guna menyelesaikan permasalahan yang ada Siswa saling berinteraksi dan memberikan kontribusinya yang terwujud dalam bentuk penjelasan, pembenaran, setuju, tidak setuju. dan terdapat pula karateristik Intertwining yang dapat mengkoneksikan kedalam kehidupan nyata. hal tersebut terlihat pada gambar dibawah ini:

\section{Perhatikan ilustrasi-ilustrasi dibawah ini!}

- Ilustrasi pertama

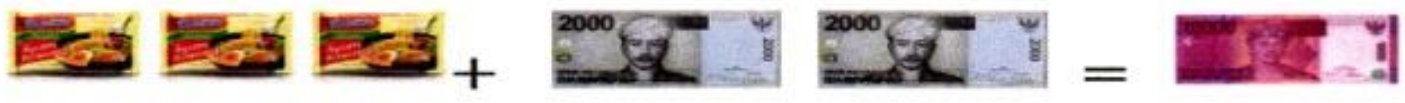

- Ilustrasi kedua

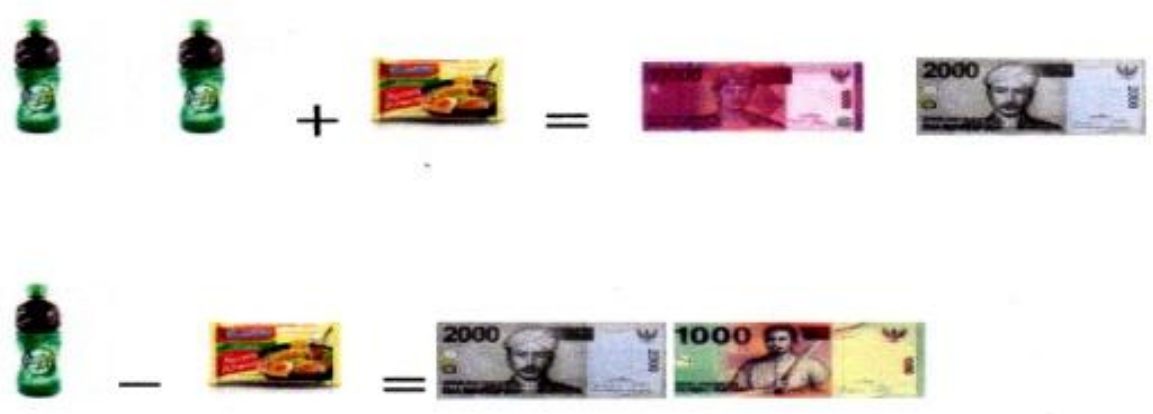

\section{Gambar 2. Keterkaitan antar konsep matematika dengan kehidupan nyata (Intertwining)}

Keterkaitan (Intertwining) pada gambar di atas, siswa akan melihat adanya jalinan atau keterkaitan antar konsep matematika dalam kehidupan sehari-hari, hal tersebut sesuai dengan indikator kemampuan koneksi matematik dimana salah satu indikator kemampuan koneksi matematik yaitu menggunakan matematika dalam kehidupan sehari-hari. Dari sini terlihat bahwa pembelajaran yang menggunakan pendekatan Realistic Mathematis Education dapat meningkatkan kemampuan koneksi matematik siswa.

Pembelajaran menggunakan pendekatan Realistic Mathematis Education juga menunjukan peran yang berarti dalam penguasaan kemampuan koneksi matematik, sesuai dengan yang di ungkapkan Treffers (Wijaya, 2012) yaitu: 1) pengunaan konteks; 2) pengunaan model; 3) menggunakan kontribusi siswa; 4) interaktif; 5) keterkaitan antar konsep matematik dengan kehidupan nyata (intertwining), yang implentasinya sudah terlaksana dilapangan dan terbukti bahwa siswa mampu mengkontruksi pengetahuan 
melalui benda-benda konkrit sebagai titik awal memahami konsep matematika dan menyampaikannya dalam diskusi kelompok. Hal ini sudah sesuai dengan penelitian yang dilakukan oleh Fitriani (2012) dengan judul "Penerapan Pendekatan Pendidikan Matematika Realistik Secara Berkelompok Untuk Meningkatkan Kemampuan Pemecahan Masalah Matematis dan Self Confidience Siswa SMP” yang menyimpulkan bahwa siswa yang mendapatkan pembelajaran dengan pendekatan PMR secara berkelompok mengalami peningkatan kemampuan pemecahan masalah matematis yang lebih baik dibandingkan dengan siswa yang mendapatkan pembelajaran matematika secara konvensional, dari penelitian tersebut kemampuan pemecahan masalah dapat meningkat sehingga kemampuan koneksi pun dapat meningkat karena sudah terlihat pada penelitian ini yang sudah dilakukan.

Hal ini sangat berbeda dengan kelas kontrol yang menggunakan pembelajaran biasa, siswa cenderung pasif karena hanya mendengarkan dan mencatat materi yang disampaikan oleh guru tanpa banyak bertanya dalam proses pembelajaran. Dalam kelas kontrol proses yang terjadi adalah guru menerangkan dan siswa hanya mendengarkan apa yang guru terangkan. Sehingga pembelajaran biasa akan membuat siswa cenderung bosan dan pasif.

\section{KESIMPULAN}

Hasil penelitian yang diperoleh yaitu pencapaian kemampuan koneksi matematik siswa SMP yang pembelajarannya menggunakan pendekatan Realistic Mathematis Education lebih baik daripada yang menggunakan pembelajaran biasa, peningkatan kemampuan koneksi matematik siswa SMP yang pembelajarannya menggunakan pendekatan Realistic Mathematis Education lebih baik daripada yang menggunakan pembelajaran biasa, serta implementasi langkah-langkah pembelajaran dengan menggunakan pendekatan Realistic Mathematis Education di lapangan sudah terlaksana.

\section{REFERENSI}

Depdiknas (2006). Permendiknas Nomor 22 Tahun 2006 Tentang Standar Isi Sekolah Menengah Atas. Jakarta: Depdiknas.

Fitriani, N. (2012). Penerapan Pendekatan Pendidikan Matematika Realistik Secara Berkelompok Untuk Meningkatkan Kemampuan Pemecahan Masalah Matematis dan Self Confidience Siswa SMP. Tesis: UPI. Bandung: tidak diterbitkan.

Hermawan (2007). Pengembangan Kurikulum dan Pembelajaran. Jakarta: Universitas Terbuka. 
NTCM (2000). Principle and Evaluation Standarts for School Mathematics. Reaston, VA: NTCM

PISA (2012). National Center For Education Statistics, PISA 2012. Tersedia: http://www.nces.ed.gov/survey/pisa/pisa2012highlight.asp.

Ramdani, Yani. (2012). Pengembangan instrumen dan bahan ajar untuk meningkatkan kemampuan komunikasi, penalaran, dan koneksi matematis dalam konsep integral. Jurnal Penelitian Pendidikan, 13(1), 44-52.

Riajanto. M. L. E. (2010). Peningkatan Kemampuan Pemahaman dan Kemampuan Pemecahan Masalah Geometri Melalui Pendekatan Matematik Realistik. Bandung: Tesis SPs UPI. tidak diterbitkan.

Sumarno, U. (2012). Bahan Ajar Mata Kuliah Proses Berpikir Matematik Program S2 Pendidikan Matematika STKIP Siliwangi 2012. Bandung: tidak diterbitkan.

Usdiyana. (2009). Meningkatkan kemampuan berpikir logis siswa SMP melalui pembelajaran matematika realistik. Jurnal Pengajaran MIPA 13.1 hal 1-14.

Wijaya, A. (2012). Pendidikan Matematika Realistik Suatu Alternative Pendekatan Pembelajaran Matematika. Yogyakarta: Graha ilmu.

Zaini, Ahmad, and Marsigit Marsigit. (2014). Perbandingan keefektifan pembelajaran matematika dengan pendekatan matematika realistik dan konvensional ditinjau dari kemampuan penalaran dan komunikasi matematik siswa." Jurnal Riset Pendidikan Matematika , 1(2) : 152-163. 